\title{
Elimination of Post-0perative Complications in Penetrating Keratoplasty by Deploying Six Sigma
}

\author{
İbrahim Şahbaz ${ }^{1}$ Mehmet Tolga Taner ${ }^{2 *}$, Üzeyir Tolga Şahandar3, Gamze Kağan4, \\ Engin Erbaş 5 \\ ${ }^{1}$ Department of Opticianry, Uskudar University, Istanbul, Turkey \\ ${ }^{2}$ Department of Healthcare Management, Uskudar University, Istanbul, Turkey \\ ${ }^{3}$ Isparta State Hospital, Isparta, Turkey \\ ${ }^{4}$ Department of Occupational Health and Safety, Uskudar University, Istanbul, Turkey \\ ${ }^{5}$ Institute of Health Sciences, Uskudar University, Istanbul, Turkey \\ Email: ${ }^{*}$ mehmettolga.taner@uskudar.edu.tr
}

Received 23 May 2014; revised 25 June 2014; accepted 2 July 2014

Copyright (C) 2014 by authors and Scientific Research Publishing Inc.

This work is licensed under the Creative Commons Attribution International License (CC BY).

http://creativecommons.org/licenses/by/4.0/

(c) (i) Open Access

\section{Abstract}

This paper shows how a public eye and research hospital in Turkey initiated Six Sigma principles to reduce the number of complications occurring after penetrating keratoplasty surgeries. Data were collected for nine years. To analyse the complications among 55 patients (59 eyes) underwent penetrative keratoplasty, main tools of Six Sigma's Define-Measure-Analyze-Improve-Control (DMAIC) improvement cycle such as SIPOC table and Failure, Mode and Effect Analysis (FMEA) were implemented. Sources and root causes of eleven types of complications were identified and reported. For a successful penetrating keratoplasty surgery patient's anatomy, suitability of donor cornea, experience of ophthalmic surgeon, sterilization and hygiene, and performance of the equipment were determined to be the "critical-to-quality" factors. The complication with the highest hazard score was found to be the glaucoma. The process sigma level of the process was measured to be 3.1418. The surgical team concluded that all types of post-operative complications should be significantly reduced by taking the necessary preventive measures.

\section{Keywords}

Six Sigma, Ophthalmology, Penetrating Keratoplasty Surgery, Post-Operative Complications

\footnotetext{
${ }^{*}$ Corresponding author.
}

How to cite this paper: Şahbaz, I., Taner, M.T., Şahandar, Ü.T., Kağan, G. and Erbaş, E. (2014) Elimination of Post-Operative Complications in Penetrating Keratoplasty by Deploying Six Sigma. American Journal of Operations Research, 4, $189-196$. 


\section{Introduction}

Corneal eye disease is the fourth most common cause of blindness after cataracts, glaucoma and age-related macular degeneration, affecting more than 10,000,000 people worldwide. Since the first successful human corneal transplant performance in 1905, the cornea transplants have become the most successful and the most common solid tissue transplant with 600,000 procedures performed in the United States over the past 40 years and [1] [2]. In 2013, more than 47,361 corneal transplants were performed in the United States resulting in nearly \$6 billion in total net benefits over the lifetime of the recipients [3].

Penetrating Keratoplasty (PKP) is a standard full thickness transplant that involves the surgical removal of the central two-thirds of the damaged cornea. With changes in medical and surgical management, one expects a decrease in the number of complications after PKP surgery. Although the surgical procedure restores vision and also relieves pain and suffering caused by injured and diseased cornea with high success rate, studies continue to show many post-operative complications such as wound leaks, malpositioning of the donor cornea, suture exposure and infections, infiltration of immune due to suture, persistent epithelial defect, filamentary keratitis, primary endothelial insufficiency, glaucoma, cataract, acute choroidal detachment, epithelial down growth, fix dilated pupils, refractive changes, graft infections, recurrent disease, shallow anterior chamber, graft rejection, hypotony, cystoid macular edema, endophtalmitis and sympathetic ophthalmia [1] [4]-[11]. In addition, residual astigmatism after PKP surgery may limit postoperative visual function and be the cause of decreased patient satisfaction in the presence of a clear graft [12]. When these complications occur, proper and prompt management is essential. Preventative measures will result in earlier visual rehabilitation and greater long-term graft survival.

PKP surgery shows an overall positive prognosis in the long term [13]. Therefore, ophthalmic surgeons are in a critical position and must be aware of all types of complications that may occur, how to avoid them and how to manage them to ensure the best possible outcomes.

The use of Six Sigma, as a quality improvement method, can improve the surgical safety, efficiency and accuracy of many ophthalmic surgeries [14]. In this study, the development a Six Sigma infrastructure in a Turkish public eye and research hospital to improve the PKP surgery process will be shown. In addition, sigma level of each type of complication will be calculated and reported.

\section{Method}

\section{Six Sigma Methodology}

As a quality improvement method, Six Sigma can be employed in order to eliminate complications encountered during and after many ophthalmic surgeries [15]. Originally initiated by Motorola, Honeywell and General Electric [16], Six Sigma is a powerful performance improvement tool that is improving the outcomes of modern healthcare processes today [17]. Although it was initially introduced in manufacturing processes, it is being implemented in diagnostic imaging processes [18]-[20], emergency room [21], paramedic backup [22], laboratory [23], cataract surgery [15] radiology [24], surgical site infections [25], Intra Lase surgery [26], LASIK surgery [27], strabismus surgery [28], intravitreal injections [29], cataract surgery in patients with pseudoexfoliation syndrome [30], pars plana vitrectomy [31], phacoemulsification cataract surgery [32], and stent insertion [14] as an effective way to improve quality, performance and productivity.

A Six Sigma process produces 3.4 defects per one million opportunities (DPMO) [33]. To eliminate defects, Six Sigma makes use of a structured methodology called DMAIC to find the root causes behind problems and to reach near perfect processes [34]. DMAIC can analyze and modify complicated time-sensitive healthcare processes involving multiple specialists and treatment areas by identifying and eliminating root causes of defects, errors or complications and thus minimizing healthcare process variability [17] [33].

To achieve this, normal distribution underlies Six Sigma’s statistical assumptions [22]. An empirically-based 1.5 sigma shift is introduced into the calculation [22]. DPMO is calculated from Equation (1) as follows:

$$
\mathrm{DPMO}=1,000,000 \times(\mathrm{B} / \mathrm{A})
$$

where A is the total number of PKP surgeries performed and B is the total number of post-operative complications occurred.

The higher level of sigma after the initiation of Six Sigma indicates a lower rate of post-operative complications and a more efficient process. 


\section{Analysis}

\section{Application of DMAIC for PKP Surgery}

The eye care center decided that Six Sigma is the best way to achieve their goals. A surgical team was assembled and trained in the methodology. Committed and consistent leadership to overcome the complications was assured by this team. The surgical team firstly generated a SIPOC (Supplier, Input, Process, Output and Customer) Table for penetrative keratoplasty surgery process (Table 1).

The surgical team defined three postoperative performance objectives, namely improved visual acuity, excellent prognosis and clear cornea. They also defined a "complication” as any unwanted outcome inhibiting the patient to be cured and stable which compounds the illness and decreases the patient's quality of life or prolongs the planned hospital stay [14]. To achieve the performance objective, the surgical team first determined the Critical-to-Quality (CTQ) factors by brainstorming. The CTQ factors were those factors that may have an influence on the objective.

The surgical team determined the metrics to measure existing process. The metrics to be chosen for a Six Sigma study were:

1) Total number of PKP surgeries performed in the eye care center,

2) Number of post-operative complications.

Data were collected for a period of 9-year on 23 females and 32 males [35]. In this period, PKP surgeries were performed on 59 eyes. Patients were aged between 8 and 78 with an average of 45.08. Complications had been noted as they occurred. The surgical team followed up the patients for 12 months and identified eleven types of complications and classified them as how soon they occur, i.e. acute and/or sub-acute and/or chronic (Table 2). Sources (Table 3) and root-causes (Table 4) of these complications were tabulated by type.

Table 1. SIPOC table for PKP surgery.

\begin{tabular}{cccc}
\hline SUPPLIER & INPUT & PROCESS & OUTPUT \\
\hline Ophthalmic surgeon & Patient & Preoperative evaluation & Improved visual acuity \\
Nurse & Donor's cornea & Evaluation of donor's cornea & Excellent prognosis \\
Technician & $\begin{array}{c}\text { Surgical material } \\
\text { (suture and viscoelastic) } \\
\text { Keratoplasty equipment }\end{array}$ & Preoperative regulation of \\
& vascular pressure & Clear cornea \\
& & Trepanation of donor's cornea & \\
\hline
\end{tabular}

Table 2. Post-operative complications experienced.

\begin{tabular}{|c|c|c|c|c|}
\hline & Complication & Acute & Sub-Acute & Chronic \\
\hline Туре I & Glaucoma & $\mathrm{X}$ & $\mathrm{X}$ & $\mathrm{X}$ \\
\hline Type II & Primary graft failure & $\mathrm{X}$ & $\mathrm{X}$ & \\
\hline Type III & Graft rejection & & $\mathrm{X}$ & $\mathrm{X}$ \\
\hline Type IV & Infectious keratitis and suture abscesses & & $\mathrm{X}$ & $\mathrm{X}$ \\
\hline Type V & Posterior capsule opafication & & & $\mathrm{X}$ \\
\hline Type VI & Anterior synechiae & & $\mathrm{X}$ & $\mathrm{X}$ \\
\hline Type VII & Cystoid macular edema & & $\mathrm{X}$ & $\mathrm{X}$ \\
\hline Type VIII & Persistent epithelial defects & $\mathrm{X}$ & $\mathrm{X}$ & \\
\hline Type IX & Corneal abscess & & $\mathrm{X}$ & $\mathrm{X}$ \\
\hline Type X & Wound leaks and iris tissue prolapse & $\mathrm{X}$ & $\mathrm{X}$ & \\
\hline Type XI & Acute choroidal detachment & $\mathrm{X}$ & & \\
\hline
\end{tabular}


Table 3. Sources of post-operative complications.

\begin{tabular}{|c|c|c|c|c|c|}
\hline & Surgeon & Staff & Patient & Equipment & Donor Cornea \\
\hline Type I & $\mathrm{X}$ & & $\mathrm{X}$ & & $\mathrm{X}$ \\
\hline Type II & $\mathrm{X}$ & & & & $\mathrm{X}$ \\
\hline Type III & & & $\mathrm{X}$ & & $\mathrm{X}$ \\
\hline Type IV & $\mathrm{X}$ & $\mathrm{X}$ & $\mathrm{X}$ & $\mathrm{X}$ & $\mathrm{X}$ \\
\hline Type V & & & $\mathrm{X}$ & & \\
\hline Type VI & $\mathrm{X}$ & & $\mathrm{X}$ & & \\
\hline Type VII & & & $\mathrm{X}$ & & \\
\hline Type VIII & & & $\mathrm{X}$ & & $\mathrm{X}$ \\
\hline Type IX & $\mathrm{X}$ & $\mathrm{X}$ & $\mathrm{X}$ & $\mathrm{X}$ & $\mathrm{X}$ \\
\hline Type X & $\mathrm{X}$ & & $\mathrm{X}$ & & \\
\hline Type XI & & & $\mathrm{X}$ & & \\
\hline
\end{tabular}

Table 4. Root-causes of post-operative complications.

\begin{tabular}{|c|c|c|c|c|c|}
\hline & $\begin{array}{c}\text { Experience of } \\
\text { Ophthalmic Surgeon }\end{array}$ & $\begin{array}{l}\text { Suitability of } \\
\text { Donor Cornea }\end{array}$ & $\begin{array}{l}\text { Sterilization } \\
\text { and Hygiene }\end{array}$ & $\begin{array}{l}\text { Patient's } \\
\text { Anatomy }\end{array}$ & $\begin{array}{l}\text { Performance } \\
\text { of Equipment }\end{array}$ \\
\hline Type I & $\mathrm{X}$ & $\mathrm{X}$ & & $\mathrm{X}$ & \\
\hline Type II & $\mathrm{X}$ & $\mathrm{X}$ & & & \\
\hline Type III & & $\mathrm{X}$ & & $\mathrm{X}$ & \\
\hline Type IV & $\mathrm{X}$ & $\mathrm{X}$ & $\mathrm{X}$ & $\mathrm{X}$ & $\mathrm{X}$ \\
\hline Type V & & & & $\mathrm{X}$ & \\
\hline Type VI & $\mathrm{X}$ & & & $\mathrm{X}$ & \\
\hline Type VII & & & & $\mathrm{X}$ & \\
\hline Type VIII & & $\mathrm{X}$ & & $\mathrm{X}$ & \\
\hline Tyре IX & $\mathrm{X}$ & $\mathrm{X}$ & $\mathrm{X}$ & $\mathrm{X}$ & $\mathrm{X}$ \\
\hline Type X & $\mathrm{X}$ & & & $\mathrm{X}$ & \\
\hline Type XI & & & & $\mathrm{X}$ & \\
\hline
\end{tabular}

The incidence of complications depended on multiple sources of variables. Measurement variables, surgeon variables, staff variables, patient variables and equipment variables were all evaluated when attempting to assess the root-cause of a complication (Table 3 and Table 4).

The surgical team analyzed the occurrence frequency of each complication (Table 4) and related them with the root-causes on Table 3. The analysis revealed that Types I, II and III were the three most frequently occurring complications in the PKP surgeries. Then, the CTQs are classified as "vital few factors" and "trivial many factors" according to how frequent they caused the complications. The "vital few" factors, i.e. the factors that had the most impact on the success of PKP surgery were determined to be patient's anatomy and donor cornea. The other factors, i.e. experience of ophthalmic surgeon, sterilization and hygiene, and equipment were found to be the "trivial many" factors.

\section{Discussion}

The surgical team calculated the current DPMO and sigma levels for each complication type (Table 5). The 
process sigma level, calculated as the arithmetic average of eleven complications, was found to be 3.1418.

The highest sigma level was obtained for Types X and XI. The lowest sigma level was found to be belong to Type I. Having sigma levels lower than 4.00 , all types of complications were alarming to be significantly reduced.

Risk assessment of PKP surgeries was achieved by FMEA. Utilization of the FMEA involved break down the process into individual steps: potential failure modes (i.e. complications), severity score, probability score, hazard score, criticality and detection, so that the surgery team could look at key drivers in the process based on the past experience.

Complication trends and their consequences over a 9-year period had been monitored and recorded. Surgical team prioritized the complications according to how serious their consequences were (i.e. severity score), how frequently they occurred (i.e. probability score) and how easily they could be detected. Hazard analysis was employed in order to identify failure modes and their causes and effects. The surgery team determined the severity of each complication and assigned scores for them. The severity of each complication was scored from 1 to 4 (Table 6).

For each complication type, the hazard score was calculated by multiplying the severity score with the probability score. Consequently, an FMEA table was drawn (Table 7). Among the complications, Type I yielded the highest hazard score. Types VI and VII were equally hazardous complications and so were Types VIII and IX. According to FMEA, Type $\mathrm{X}$ was the least hazardous complication.

The surgical team developed preventative measures for each type of complication in order to bring the overall process under control. They implemented a corrective action plan to reduce and/or eliminate the complications (See Appendix).

\section{Conclusions}

In this study, authors identified and reported eleven types of post-operative complications encountered after PKP surgeries. These complications were almost always related to events that had occurred during surgery. The process sigma level of the overall process (i.e. cataract surgeries made in 9 years) was measured to be 3.1418.

Many complications were related to the suitability of the donor cornea and patient's anatomy. Other rootcauses were determined to be experience of ophthalmic surgeons, performance of equipment, and hygiene and

Table 5. Cumulative frequency, DPMO and sigma levels.

\begin{tabular}{rcccc}
\hline & Count & Frequency (\%) & DPMO & Sigma Level \\
\hline Type I & 13 & 27.12 & 271186 & 2.11 \\
Type II & 6 & 10.17 & 101695 & 2.77 \\
Type III & 4 & 6.78 & 67797 & 2.99 \\
Type IV & 4 & 6.78 & 67797 & 3.14 \\
Type V & 3 & 5.08 & 50847 & 3.33 \\
Type VI & 2 & 3.39 & 33898 & 3.33 \\
Type VII & 2 & 3.39 & 33898 & 3.33 \\
Type VIII & 2 & 3.39 & 33898 & 3.33 \\
Type IX & 2 & 3.39 & 33898 & 3.62 \\
Type X & 1 & 1.69 & 16949 & 3.62 \\
Type XI & 1 & 1.69 & 16949 & \\
\hline
\end{tabular}

Table 6. Severity scores.

\begin{tabular}{ccccc}
\hline Severity Score & $\mathbf{4}$ & $\mathbf{3}$ & $\mathbf{2}$ & $\mathbf{1}$ \\
\hline Severity of Complication & Death or Permanent harm & Temporary harm & Bias & No harm \\
\hline
\end{tabular}


Table 7. FMEA table.

\begin{tabular}{cccccc}
\hline \multirow{2}{*}{ Complication Type } & & Hazard Analysis & & \multicolumn{2}{c}{ Decision Tree Analysis } \\
\cline { 2 - 6 } & Severity Score & Probability Score & Hazard Score & Critical? & Detectable? \\
\hline Type I & 2 & 0.2712 & 0.5424 & Yes & Yes \\
Type II & 4 & 0.1017 & 0.4068 & Yes & No \\
Type III & 4 & 0.0678 & 0.2712 & Yes & Yes \\
Type IV & 3 & 0.0678 & 0.2034 & Yes & Yes \\
Type V & 1 & 0.0508 & 0.0508 & No & Yes \\
Type VI & 2 & 0.0339 & 0.0678 & No & No \\
Type VII & 2 & 0.0339 & 0.0678 & Yes & Yes \\
Type VIII & 3 & 0.0339 & 0.1017 & Yes & Yes \\
Type IX & 3 & 0.0339 & 0.1017 & Yes & Yes \\
Type X & 1 & 0.0169 & 0.0169 & Yes & No \\
Type XI & 4 & 0.0169 & 0.0676 & &
\end{tabular}

sterilization. The complication rates were reduced as ophthalmic surgeons gained experience and was trained on how to identify, minimize or eliminate the sources and root-causes of the complications. Sterilization of the operating room, equipment and instruments as well as the regular maintenance and calibration of the equipment were also essential.

Nonetheless, the surgical team concluded that the risks associated with PKP surgery could be minimized by taking the necessary preventative measures with appropriate preoperative, intraoperative and postoperative care.

\section{References}

[1] Krachmer, J.H., Mannis, M.J. and Holland, E.J. (2005) Cornea. 2nd Edition, Elsevier, Mosby.

[2] Al-Yousuf, N., Mavrikakis, I., Mavrikakis, E. and Daya, S.M. (2004) Penetrating Keratoplasty: Indications over a 10Year Period. British Journal of Ophthalmology, 88, 998-1001. http://dx.doi.org/10.1136/bjo.2003.031948

[3] EBAA (Eye Bank Association of America) (2013) Cost-Benefit Analysis of Corneal Transplant. http://www.restoresight.org/wp-content/uploads/2013/10/Lewin-Study-Executive-Summary-.pdf

[4] Muraine, M., Christian, S. and Laure, W. (2003) Long Term Results of Penetrating Keratoplasty. Graefe's Archive for Clinical and Experimental Ophthalmology, 681-699.

[5] Severin, M. and Bartz-Schmidt, K.U. (2000) Penetrating Keratoplasty: Diagnosis and Treatment of Postoperative Complications. Springer-Verlag GmbH, Berlin. http://dx.doi.org/10.1007/978-3-642-59684-1

[6] Saylı, M. and Akarçay, K. (2002) Penetrating Keratoplasty: Indications and Postoperative Rehabilitation. Seminar Notes of Assistant Ophthalmic Surgeons, Istanbul.

[7] Ing, J.J., Ing, H.H., Nelson, L.R., Hodge, D.O. and Bourne, W.M. (1998) Ten-Year Postoperative Results of Penetrating Keratoplasty. Ophthalmology, 105, 1855-1865. http://dx.doi.org/10.1016/S0161-6420(98)91030-2

[8] Tavakkoli, H. and Sugar, J. (1994) Microbial Keratitis Following Penetrating Keratoplasty. Ophthalmic Surgery, 25, 356-360.

[9] Kloess, P.M., Stulting, R.D., Waring, G.O. and Wilson, L.A. (1993) Bacterial and Fungal Endolpthaimitis after Penetrating Keratoplasty. American Journal of Ophtalmology, 115, 309-316.

[10] Stemberg, P., Meredith, T.A., Steward, M.A. and Kaplan, H.J. (1990) Retinal Detachment in Penetrating Keratoplasty Patients. American Journal of Ophthalmology, 109, 148-152.

[11] Foulks, G.N. (1987) Glaucoma Associated with Penetrating Keratoplasty. Ophthalmology, 94, 871-874. http://dx.doi.org/10.1016/S0161-6420(87)33542-0

[12] Wade, M., Steinert, R.F., Garg, S., Farid, M. and Gaster, R. (2013) Results of Toric Intraocular Lenses for Post-Penetrating Keratoplasty Astigmatism. Ophthalmology, 121, 771-777. http://dx.doi.org/10.1016/j.ophtha.2013.10.011 
[13] Fasolo, A., Capuzzo, C., Fornea, M., Franch, A., Birattari, F., Carito, G., Cucco, F., Prosdocimo, G., Sala, M., DelleNoci, N., Primavera, V., Frigo, A., Grigoletto, F., Ponzin, D. and Cortes Study Group (2011) Risk Factors for Graft Failure after Penetrating Keratoplasty: 5-Year Follow-Up from the Corneal Transplant Epidemiological Study. Cornea, 30, 1328-1335. http://dx.doi.org/10.1097/ICO.0b013e318206895a

[14] Taner, M.T., Kagan, G., Celik, S., Erbas, E. and Kagan, M.K. (2013) Formation of Six Sigma Infrastructure for the Coronary Stenting Process. International Review of Management and Marketing, 3, 232-242.

[15] Taner, M.T. (2013) Application of Six Sigma Methodology to a Cataract Surgery Unit. International Journal of Health Care Quality Assurance, 26, 768-785. http://dx.doi.org/10.1108/IJHCQA-02-2012-0022

[16] Mehrjerdi, Y.Z. (2011) Six Sigma: Methodology, Tools and İts Future. International Journal of Assembly Automation, 31, 79-88. http://dx.doi.org/10.1108/01445151111104209

[17] Taner, M.T., Sezen, B. and Antony, J. (2007) An Overview of Six Sigma Applications in Healthcare Industry. International Journal of Health Care Quality Assurance, 20, 329-340. http://dx.doi.org/10.1108/09526860710754398

[18] Antony, J. and Banuelas, R. (2002) Key Ingredients for the Effective Implementation of Six Sigma Program. Measuring Business Excellence, 6, 20-27. http://dx.doi.org/10.1108/13683040210451679

[19] Antony, J., Antony, F.J., Kumar, M. and Cho, B.R. (2007) Six Sigma in Service Organisations: Benefits, Challenges and Difficulties, Common Myths, Empirical Observations and Success Factors. International Journal of Quality and Reliability Management, 24, 294-311. http://dx.doi.org/10.1108/02656710710730889

[20] Taner, M.T., Sezen, B. and Atwat, K.M. (2012) Application of Six Sigma Methodology to a Diagnostic Imaging Process. International Journal of Health Care Quality Assurance, 25, 274-290. http://dx.doi.org/10.1108/09526861211221482

[21] Miller, M.J., Ferrin, D.M. and Szymanski, J.M. (2003) Simulating Six Sigma Improvement Ideas for a Hospital Emergency Department. Proceedings of the IEEE Winter Simulation Conference, New Orleans, 7-10 December 2003, 1926-1929.

[22] Taner, M.T. and Sezen, B. (2009) An Application of Six Sigma Methodology to Turnover Intentions in Healthcare. International Journal of Health Care Quality Assurance, 22, 252-265. http://dx.doi.org/10.1108/09526860910953520

[23] Nevalainen, D., Berte, L., Kraft, C., Leigh, E., Picaso, L. and Morgan, T. (2000) Evaluating Laboratory Performance on Quality Indicators with the Six Sigma Scale. Archives of Pathology and Laboratory Medicine, 124, 516-519.

[24] Cherry, J. and Seshadri, S. (2000) Six Sigma: Using Statistics to Reduce Process Variability and Costs in Radiology. Radiology Management, 22, 42-49.

[25] Pexton, C. and Young, D. (2004) Reducing Surgical Site Infections through Six Sigma and Change Management. Patient Safety and Quality Healthcare, 1, 1-8.

[26] Sahbaz, I., Taner, M.T., Eliacik, M., Kagan, G. and Erbas, E. (2014) Adoption of Six Sigma’s DMAIC to Reduce Complications in IntraLase Surgeries. International Journal of Statistics in Medical Research, 3, 126-133. http://dx.doi.org/10.6000/1929-6029.2014.03.02.6

[27] Taner, M.T., Kagan, G., Sahbaz, I., Erbas, E. and Kagan, S.B. (2014) A Preliminary Study for Six Sigma Implementation in Laser in Situ Keratomileusis (LASIK) Surgeries. International Review of Management and Marketing, 4, 24-33.

[28] Taner, M.T., Sahbaz, I., Kagan, G., Atwat, K. and Erbas, E. (2014) Development of Six Sigma Infrastructure for Strabismus Surgeries. International Review of Management and Marketing, 4, 49-58.

[29] Sahbaz, I., Taner, M.T., Eliacik, M., Kagan, G., Erbas, E. and Enginyurt, H. (2014) Deployment of Six Sigma Methodology to Reduce Complications in Intravitreal Injections. International Review of Management and Marketing, 4, 160-166.

[30] Sahbaz, I., Taner, M.T., Kagan, G., Sanisoglu, H., Durmus, E., Tunca, M., Erbas, E., Kagan, S.B., Kagan, M.K. and Enginyurt, H. (2014) Development of a Six Sigma Infrastructure for Cataract Surgery in Patients with Pseudoexfoliation Syndrome. Archives of Business Research, 2, 15-23. http://dx.doi.org/10.14738/abr.22.173

[31] Sahbaz, I., Taner, M.T., Sanisoglu, H., Kar, T., Kagan, G., Durmus, E., Tunca, M., Erbas, E., Armagan, I. and Kagan, M.K. (2014) Deployment of Six Sigma Methodology to Pars Plana Vitrectomy. International Journal of Statistics in Medical Research, 3, 94-102. http://dx.doi.org/10.6000/1929-6029.2014.03.02.3

[32] Sahbaz, I., Taner, M.T., Kagan, G., Sanisoglu, H., Erbas, E., Durmus, E., Tunca, M. and Enginyurt, H. (2014) Deployment of Six Sigma Methodology in Phacoemulsification Cataract Surgeries. International Review of Management and Marketing, 4, 123-131.

[33] Buck, C. (2001) Application of Six Sigma to Reduce Medical Errors. Annual Quality Congress Proceedings, Charlotte, 11-15 April 2001, 739-742.

[34] Park, S.H. and Antony, J. (2008) Robust Design for Quality Engineering and Six Sigma. World Scientific Publishing, New Jersey. http://dx.doi.org/10.1142/6655

[35] Sahandar, U.T. (2005) Our Penetrating Keratoplasty Results, Istanbul. Doctor of Medicine Thesis. 


\section{Appendix}

\begin{tabular}{|c|c|c|}
\hline Complication Type & Complication Name & Preventative Measure(s) \\
\hline Type I & Glaucoma & $\begin{array}{l}\text { - } \quad \text { Strictly monitor the cases with glaucoma. } \\
\text { - } \quad \text { Control inflammation postoperatively. } \\
\text { - } \quad \text { Be careful with pigment dispersion. } \\
\text { - } \quad \text { Control the haemorrhage. } \\
\text { - } \quad \text { Clean the viscoelastic agents well. }\end{array}$ \\
\hline Type II & Primary graft failure & $\begin{array}{l}\text { - } \quad \text { Do not use cornea with abnormal donor endothelium. } \\
\text { - } \quad \text { Be careful not to cause incorrect corneal stroge. } \\
\text { - } \quad \text { Make sure that surgical trauma is minimum. }\end{array}$ \\
\hline Туре III & Graft rejection & None \\
\hline Type IV & $\begin{array}{l}\text { Infectious keratitis } \\
\text { and suture abscesses }\end{array}$ & $\begin{array}{l}\text { - } \quad \text { Cure keratitis sicca, blepharitis, acne rosacea, cicatricial conjunctival } \\
\text { - } \quad \text { Makease, trichiasis and trachoma during the preoperative period. } \\
\text { - } \quad \text { If epithelia does not contaminate during the intraoperative period. } \\
\text { postoperatively. } \\
\text { - } \text { Make sure that exposed or loose sutures does not happen. } \\
\text { - } \quad \text { Be careful with the hygiene if contact lens are used. } \\
\text { - } \quad \text { Carefully follow-up the graft failure development. } \\
\text { - Carefully follow-up the patients with atopic disease, systemic } \\
\text { - } \quad \text { immuno-suppression, diabetes, rheumatoid disease. } \\
\text { - Be careful while administering corticosteroids. }\end{array}$ \\
\hline Type V & Posterior capsule opafication & None \\
\hline Type VI & Anterior synechiae & - If synechial formation occurs,control the inflammation. \\
\hline Type VII & Cystoid macular edema & $\begin{array}{l}\text { - } \quad \text { Be careful that vitreous corneal touch does not occur. } \\
\text { - } \quad \text { Make sure that vitreous incarceration in the wound does not happen. } \\
\text { - } \quad \text { Be very careful that photic damage from the surgical microscope } \\
\text { does not happen. }\end{array}$ \\
\hline Type VIII & Persistent epithelial defects & $\begin{array}{l}\text { - Make sure that the predisposing factors are treated before } \\
\text { - } \quad \text { Use only donor tissue that has excellent epithelium. } \\
\text { - } \quad \text { Careful tissue handling is necessary. } \\
\text { - } \text { Avoid excessive irrigation. } \\
\text { - Keep the epithelium hydrated by isoelastic agents during the } \\
\text { intraocular procedure. }\end{array}$ \\
\hline Type IX & Corneal abscess & $\begin{array}{l}\text { - } \quad \text { Make sure about sterilization and hygiene. } \\
\text { - Treat the eye and eyelid infections preoperatively. }\end{array}$ \\
\hline Type X & Wound leaks and iris tissue prolapse & $\begin{array}{l}\text { - } \quad \text { Carefully examine before completing the surgical procedure. } \\
\text { - } \quad \text { Avoid brunts after the surgery. }\end{array}$ \\
\hline Type XI & Acute choroidal detachment & $\begin{array}{l}\text { - Be careful with elderly patients. } \\
\text { - } \text { Make sure that intraocular pressure is under control. } \\
\text { - } \text { Avoid performing intraoperative valsalva maneuvers. } \\
\text { - } \quad \text { Be carefulate the systemic hypertension. } \\
\text { - }\end{array}$ \\
\hline
\end{tabular}


Scientific Research Publishing (SCIRP) is one of the largest Open Access journal publishers. It is currently publishing more than 200 open access, online, peer-reviewed journals covering a wide range of academic disciplines. SCIRP serves the worldwide academic communities and contributes to the progress and application of science with its publication.

Other selected journals from SCIRP are listed as below. Submit your manuscript to us via either submit@scirp.org or Online Submission Portal.
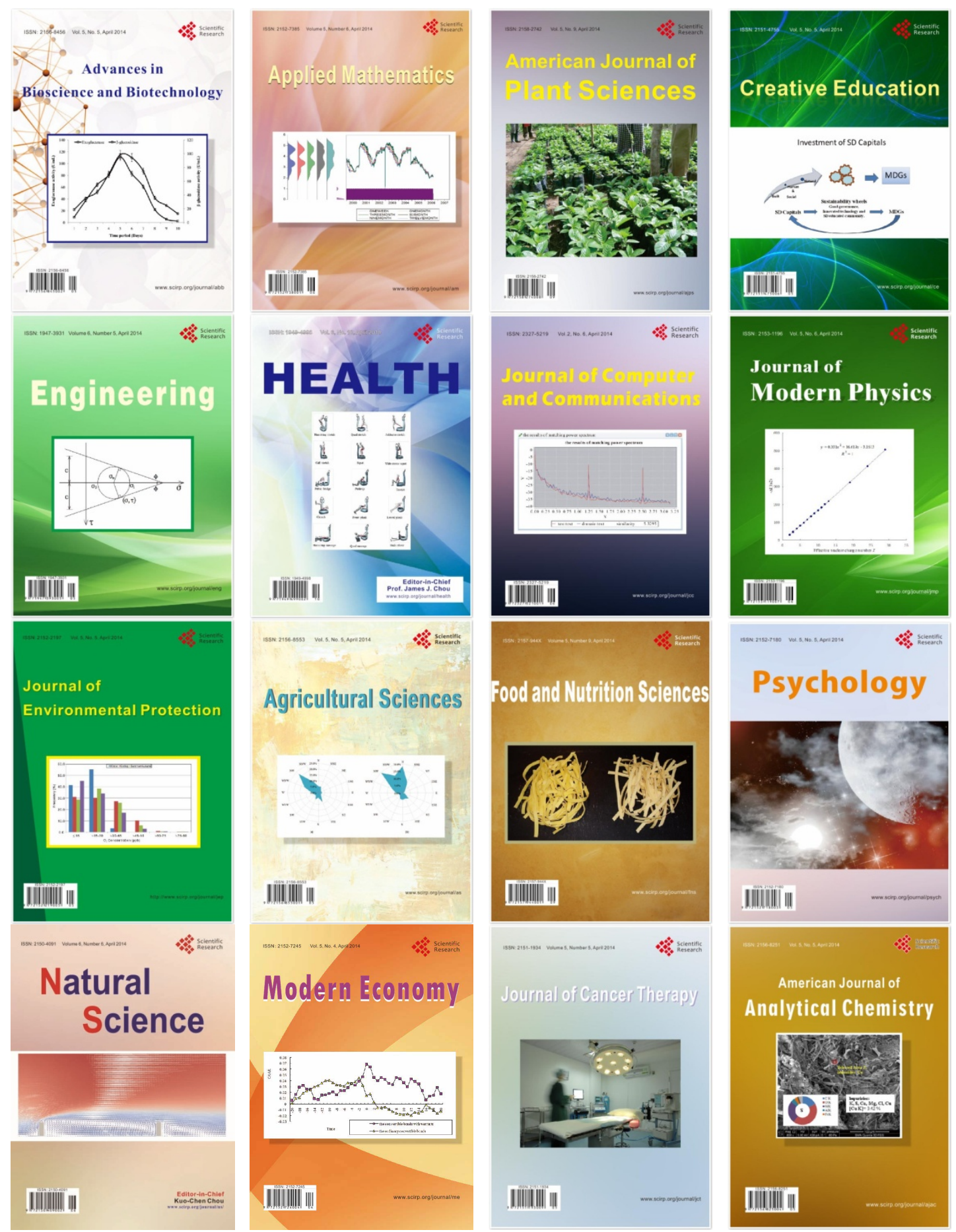